\title{
De Guadalupes a borbonistas: desarrollo y proyección política de Fagoaga, Sardaneta y Sánchez de Tagle (1808-1824)
}

María Luna Argudín

EL COLEGIO DE MÉXICO

Con base en el estudio de estos tres actores se analiza la formación del núcleo del grupo político conocido como monárquicos borbonistas desde su participación en la organización secreta de Los Guadalupes, hasta los cargos de elección que desempeñaron. Se plantea como un caso ejemplar la permanencia de las elites coloniales en los cargos gubernamentales como consecuencia de la continuidad institucional.

LOS ACTORES Y EL ESCENARIO

i se puede decir que un grupo de familias constituyera un centro de poder colonial, lo constituían los hermanos Fagoaga y Bassoco, junto con sus cuñados Castañiza y Villaurrutia que ocupaban puestos tanto en la Iglesia como en la judicatura", afirma David Brading. A ellos habría que agregar a los Sardaneta, miembros del Tribunal de Minería y dueños de las minas La Valenciana y Rayas, y a los

' Brading, Mineros, 1976, p. 282.
Sánchez de Tagle, familia que también era noble y estaba emparentada con los Fagoaga.

El presente ensayo se ocupa de la proyección y desarrollo político de tres de sus hijos: José María Fagoaga, Mariano Sardaneta, marqués de San Juan de Rayas; y Manuel Francisco Sánchez de Tagle.

Fagoaga, Sánchez de Tagle y Sardaneta formaban parte de la elite minera guanajuatense, pero sus inversiones estaban altamente diversificadas por lo que también fungieron como prestamistas, hacendados y participaron en el comercio de ultramar tal y como 
era frecuente entre la elite novohispana.

José María y Manuel Francisco eran peninsulares por nacimiento pero ambos eran hijos de padres criollos. Sardaneta, en cambio, era guanajuatense. Los tres fueron educados en la ciudad de México y pronto desempeñaron altos cargos en el funcionariado virreinal. Francisco Manuel fue regidor perpetuo del Ayuntamiento de México desde 1805, José María en 1810 obtuvo en la península el nombramiento de alcalde de corte honorario de la Real Audiencia de México, y Mariano se convirtió en administrador general del Tribunal de Minería en 1808. Además, José María estaba emparentado por matrimonio con otro personaje fundamental del autonomismo de 1808: Jacobo de Villaurrutia. ${ }^{2}$

Poco se sabe sobre la manera en que las reformas borbónicas afectaron a los intereses económicos de los que poco después serían furiosos autonomistas. Gracias a los estudios de Brading se conoce parcialmente la manera en que afectó a la familia Fagoaga. ${ }^{3}$

${ }^{2}$ José María Fagoaga se casó en 1801 con su prima en primer grado, Josefa María Fagoaga y Villaurrutia, cuarta hija del marqués del Aparta. do, de manera que Jacobo de Villaurrutia se convirtió en tío político de José María. Pescador, Bautizados, 1992, p. 206.

3 En 1778 la corona dio por terminado el contrato de concesión del Apartado del que los Fagoaga disfrutaban pagándoles una muy corta suma por concepto de indemnización y en 1801 se Jes exigió el pago retroactivo de los impues. tos. En 1779, obtuvieron de la corona una exención total de impuestos y el abastecimiento de mercurio a precio de costo, para iniciar la rehabilitación de la mina de Veta Grande. Sólo con estas concesiones-afirma Brading-los Fagoaga conservaron a flote la firma. La suma que debian
Sin embargo, no se ha investigado con profundidad si la pérdida de privilegios para este sector social fue una variable determinante en su conversión al liberalismo. Lo cierto es que los Fagoaga liberales e independentistas fueron casi todos: Jacobo Villaurrutia, José María, José Mariano y Francisco (hermano de la esposa de José María). Únicamente Juan José, el hermano encargado de la administración de los bienes familiares, permanecería del lado del virrey Félix Calleja.

\section{LOS GuADALUPES}

El punto de partida de la formación del grupo político borbonista al que pertenecieron de manera destacada nuestros tres actores se puede fijar en la crisis política provocada por la invasión napoleónica a España. En 1808 el Ayuntamiento de México, apoyado por el virrey Iturrigaray, recomendaba que se convocara a un congreso general novohispano que guardaría el trono a Fernando VII. Asimismo se establecería una junta de gobierno que representaría a los súbditos por clase y estamento. ${ }^{4}$ Renacieron las antiguas teorías pactistas de los tiempos de la dinastía Habsburgo por las cuales el rey regía comunidades diversas sobre las cuales ejercía su autoridad según las leyes y costumbres locales. Los autonomistas

pagar en 1801 por impuestos ascendía a 939100 pesos; la mayor parte les fue condonado y en cambio otorgaron un préstamo a la corona que había sido convenido años atrás con el marqués del Apartado, Brading, Mineros, pp. 245-248.

4 Zárate, Guerra, 1967, pp. 54-55. 


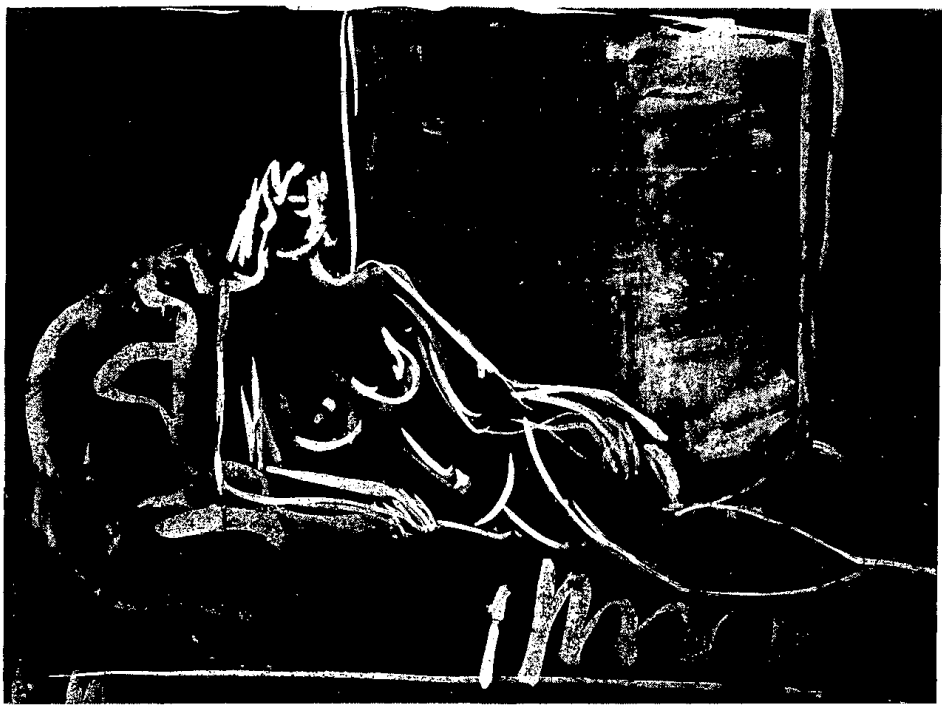

argumentaban que la ausencia del rey rompió el pacto con el reino. ${ }^{5}$

Gabriel de Yermo en 1808 encabezó un golpe de Estado en contra de Iturrigaray. La aprehensión del virrey canceló la posibilidad de decidir la crisis en el marco institucional dando paso a la formación de grupos y conspiradores autonomistas. Nuestro grupo empezó a formarse en las tertulias que se celebraban en la casa del marqués de San Juan de Rayas para libertar al virrey. Los parroquianos estaban unidos por lazos de profesión, sociales, de amistad e incluso familiares.

Después de las frustradas conspiraciones de Valladolid y de Querétaro, en 1810 bajo la convocatoria de Jacobo

${ }^{5}$ Guerra, México, 1988, pp. 186 y 191.
Villaurrutia y Mariano Sardaneta comenzó a darse forma a una organización secreta conocida como Los Guadalupes ${ }^{6}$ que apoyó a Ignacio López Rayón. Por iniciativa de este insurgente el 18 de agosto de 1811 se instaló en Zitácuaro la Suprema Junta Nacional Americana (integrada por Rayón, José Sixto Verduzco y José María Liceaga), en el mismo tenor de las juntas que se habían formado en la península y que

${ }^{6}$ La denominación era simbólica y se refería a la Virgen de Guadalupe, patrona de las fuerzas insurgentes, la capitana de América. Mientras que los militares realistas enfrentaban otra advocación: la Virgen de los Remedios, armada por éstos mariscala. Ambas lucharon en los campos de batalla, en los púlpitos y en los sermones. De la Torre Villar, Guadalupes, 1966, p. XXVI. 
tenían por objeto gobernar al reino en nombre de Fernando VII y en ausencia de éste, y en ese sentido, se inscribía en las propuestas del Ayuntamiento de 1808.

El propio Rayón también elaboró un documento con el título Elemen. tos constitucionales (1811) en cuya exposición de motivos destacaba que las juntas peninsulares que habían sustituido al gobierno de los Borbones conducían a España "al borde de su destrucción". Ello, según Rayón, hubiera bastado para justificar la "independencia de América" pero agregó un segundo argumento: los europeos en América habían desatado un "absoluto despotismo". 7 Por lo tanto, en el artículo $4^{\circ}$ señalaba que "la América es libre e independiente de toda nación" y en el $5^{\circ}$ se estableció que "la soberanía dimana inmediatamente del pueblo, reside en la persona del señor don Fernando VII y su ejercicio en el Supremo Congreso". ${ }^{8}$

Conviene detenerse brevemente en estos artículos ya que serían elementos nodales én el pensamiento borbonista. Retoma los antiguos preceptos pactistas en que la comunidad recupera la soberanía y es representada por el Supremo Congreso. Sin embargo, establecía una doble soberanía al mantener el principio tradicional de autoridad: el rey como depositario de la soberanía. Los principios liberales que unían a Los Guadalupes y que también se expresaban en los Elementos constitucionales eran la defensa de los de-

${ }^{7}$ Elementos constitucionales, en Tena, Leyes, 1988, pp. 23-24.

${ }^{8}$ Ibid. rechos civiles de los súbditos de corte jus naturalista y la monarquía constitucional, en un esfuerzo por crear un Estado de derecho.

Los Guadalupes eran una organización secreta formada por 45 miembros en la que se encontraban hombres de todos los rangos sociales: nobles, comerciantes, letrados, militares, eclesiásticos y paisanos, que apoyaban a los insurgentes, en particular a López Rayón y a José María Morelos. ${ }^{9}$ La formación de la Junta y los Elementos constitucionales fueron recibidos por este grupo como el establecimiento de un gobierno alterno que coordinaría la insurrección. ${ }^{10}$

La sociedad secreta transmitía a los rebeldes información confidencial, que obtenían gracias a los altos puestos que sus principales miembros ocupaban en la burocracia virreinal. Ello les permitió hacer llegar a los insurgentes información político-militar, y ejemplares de la Constitución de Cádiz y los Diarios de las Cortes. Más aún, Los Guadalupes les proporcionaron imprentas e impresores, incluso ayudaron a Carlos María de Bustamante a pasar a las filas insurgentes.

En 1812, con la constitución gaditana en vigor, la libertad de imprenta sólo funcionó por dos meses, ya que el virrey Venegas, preocupado por las publicaciones que se hacían, consultó a la Audiencia sobre la conveniencia de suprimir la Ley. Durante los 60 días que duró la libertad de imprenta, los materiales antes de ser publicados de-

9 Véase el apéndice que se ofrece en ibid., pp. 360-383.

${ }^{10}$ Guedea, Busca, 1992, pp. 65 y 238. 
bían de examinarse por la Junta Provincial de Censura. Los diarios sujetos a revisión eran la Gazeta del Gobierno de México, examinada por José María Fagoaga y $\mathrm{El}$ Amigo de la Patria, periódico en favor de los españoles cuya censura quedó a cargo de Pedro Fonte y Agustín Pomposo Fernández. Fagoaga trató de proteger las publicaciones que hacían causa a la independencia, en particular El Jugetillo de Carlos María Bustamante y el Pensador Mexicano de José Joaquín Fernández de Lizardi, pero sin que sus actividades se hiciesen sospechosas a las autoridades realistas. ${ }^{11}$

Los Guadalupes estaban convencidos de la necesidad de contar con sus propios órganos informativos como el medio más apropiado para atraerse a los medios ilustrados. El mismo virrey Calleja en 1813 reconoció la importancia que la prensa tenía para los insurgentes.

Los mismos Diarios de las Cortes han suministrado materiales a los escritores rebeldes para hacernos una guerra incontrarrestable; y aprovechándose de sus luces de un modo maligno como el presentar dislocados los principios liberales del Congreso, torcer su fundamento y sentido y considerarse en el caso de nación separada para aplicarse sus consecuencias, les ha propiciado este medio más prosélitos que las ventajas que alguna vez han podido lograr sus armas. Este manejo astuto y depravado es el que se observa en los periódicos que con los títulos de Semanario Patriótico Americano, Ilustrador Americano, Correo Americano del Sur, y

11 Neal, "Libertad", 1985, p. 105. otros, imprimen los rebeldes en los puntos que alternativamente ocupan. ${ }^{12}$

La Junta de Censura protestó enérgicamente, aunque sin éxito, ante las Cortes por la supresión de la libertad de imprenta. ${ }^{13}$

\section{LOS CARGOS DE ELECCIÓN}

La Constitución gaditana introdujo en 1812 la elección popular de los miembros de los ayuntamientos, en la que Los Guadalupes participaron activamente en dos niveles. Uno, abierto y formal en el proceso electoral. El otro, informal y oculto, que aprovechó una coyuntura favorable para promover sus intereses. ${ }^{14}$

El proceso electoral se inició el 29 de noviembre de 1812. Según el cómputo de la población capitalina debían de elegirse a 25 electores. Los Guadalupes lograron que fuesen designados

12 "Comunicación de don Félix María Calleja al ministro de Gracia y Justicia, 20 de junio de 1813", De la Torre Villar, Guadalupes, 1966, p. 30 .

13 La Junta de Censura envió tres documentos. El primero, fechado el 15 de octubre de 1812 , informaba sobre las dilaciones innecesarias que Venegas había opuesto para la aplicación de la Ley de Imprenta. Los otros dos documentos tenían por fecha el 12 de diciembre, $y$ daban cuenta de "la escandalosa supresión" de la ley, decretada por Venegas con la venia de la Audiencia, bajo el pretexto de abusos de im. prenta. Neal, "Libertad", p. 109. En ultramar el Consejo de Estado decidió que "la suspensión de los derechos otorgados por el código político debía de subsistir hasta que las circunstancias variasen, no pudiendo emitir juicio ninguno respecto a la responsabilidad del virrey y de la Audiencia", Zárate, Guerra, 1967, p. 367.

${ }^{14}$ Guedea, Busca, 1992, p. 354. 
como electores de parroquia varios de sus miembros: José María Fagoaga, quien se desempeñaba como síndico desde 1811, José María Alcalá, Pedro Dionisio de Cárdenas, Agustín Gallegos, Antonio Ignacio López Matoso, Juan Nazario Peimbert y Hernández, Ricardo Pérez Gallardo, Juan Bautista Raz y Guzmán y José Manuel Zozaya Bermúdez.

El virrey Venegas temeroso de que los electores formaran un Ayuntamiento integrado por criollos y de que los comicios distritales fomentaran las aspiraciones revolucionarias, suspendió el proceso electoral a fines de diciembre y ordenó que siguièra en funciones el antiguo Ayuntamiento, pero en éste también estaban infiltrados Los Guadalupes. ${ }^{15}$

Félix Calleja remplazó a Venegas en el cargo de virrey en marzo de $1813, y$ el 4 de abril, por órdenes de Calleja, los electores nombrados en noviembre escogieron a los miembros del primer Ayuntamiento constitucional de la ciudad de México. ${ }^{16}$ Los Guadalupes, por primera vez, consiguieron controlar y dirigir el proceso electoral y con ello al Cabildo, es decir, "controlaban el espacio urbano capitalino". ${ }^{17}$

La importancia política que tenían los regidores del Ayuntamiento, y en particular el síndico procurador del común, radicaba en que su función era salvaguardar los derechos de los vecinos de la localidad. ${ }^{18} \mathrm{Al}$ iniciarse

15 Estos eran Joaquín Caballero de los Olivos, José María Fagoaga y Sánchez de Tagle.

16 Cunnif, "Reforma", pp. 81, 84-85.

17 Guedea, p. 355.

${ }^{18}$ Cunnif, "Reforma", p. 68. el siglo XIX los cargos municipales estaban profundamente desprestigiados de-bido a que habían quedado sin ningún poder efectivo, sus funciones eran meramente ceremoniales y estaban controladas por un funcionario nombrado por la corona que encabezaba a esta corporación. A partir de 1808 el Ayuntamiento había adquirido una nueva significación como cuerpo en el que residía la soberanía y el síndico retomó su función primigenia como protector de los habitantes frente al poder de la corona. En 1812 el texto constitucional gaditano introdujo en el Ayuntamiento un cambio cualitativo transformándolo de una corporación cerrada en un cuerpo de elección popular con voto indirecto en segundo grado. ${ }^{19}$

Los Guadalupes también tuvieron acceso a un nuevo órgano de representación creado por la constitución española: la Diputación Provincial. Por México fueron electos en 1813 José María Fagoaga, Miguel Guridi y Alcocer, y como suplente José Antonio Cristo y Conde. La elección de Alcocer fue impugnada. Nettie Lee Benson señala que tal vez se debió a que los tres miembros de la Diputación pertenecían a la sociedad llamada de Los Guadalupes, contra los cuales se había abierto proceso por infidencia. Los Guadalupes el 5 de agosto relataban a Morelos que:

Al día siguiente, según la nueva Constitución, se procedió a la elección de vocales para Junta Provincial, eligiendo dos y un suplente por México, por estar

${ }^{19}$ Ibid., p. 67. 
ocupada Oaxaca por V.E., y aquí fue el mayor golpe que se les dio, pues fueron electos Alcocer, ex diputado a Cortes y don José María Fagoaga, europeo de nacimiento pero criado y educado en el reino, al que es muy adicto, de ideas liberales y hombre de bien, siendo esto lo que más sintieron nuestros enemigos, pues para ellos es peor Fagoaga que el americano más insurgente; y para suplente el licenciado Cristo, habanero de naturaleza y sujeto propio para el caso. ${ }^{20}$

Terminó el año de 1813 sin que se pudiese reunir la Diputación, ya que Calleja impugnó la elección probablemente por las facultades con las que contaba esta institución: podía aprobar las contribuciones que recaían en los habitantes y vigilar la inversión de los fondos públicos; esta última atribución le permitía, llegado el caso, disminuir los gastos militares que el virrey necesitaba erogar para hacer frente a la insurrección. Asimismo, desempeñaba un papel fundamental en la reactivación de los ayuntamientos al estar encargada de velar por que éstos se establecieran en la provincia, y lo que constituía una mayor amenaza para el gobierno virreinal, era que a la Diputación correspondía dar a conocer en las Cortes los abusos gubernamentales se infracciones a la Constitución que se registraran en Nueva España.21

A fines de mayo de 1814 se logró nombrar a todos los diputados que conformarían esta corporación y en la

20 "Carta de Los Guadalupes a don José María Morelos, 5 de agosto de 1813", en De la Torre Villar, Guadalupes, p. 51 y citado por Benson, Diputacion, p. 36.

21 Tena, Leyes, 1988, p. 98. que se mantuvieron Alcocer y Fagoaga por México. ${ }^{22}$ No obstante, la Diputación fue instalada el 13 de julio de 1814 , lo que permitió a Los Guadalupes preparar candidatos a Cortes y lograron que resultaran electos como diputados propietarios a éstas el licenciado José Antonio Cristo y Conde, electo en 1813 como suplente de la Diputación Provincial; Sánchez de Tagle, regidor constitucional; Ignacio Adalid, también regidor constitucional; José María Fagoaga, y el licenciado Félix Lope de Vergara, electo en 1813 como diputado a Cortes pero que no había podido trasladarse a la península. ${ }^{23}$

Es posible que Del Cristo y Fagoaga, dos de los tres electos por México para formar la Diputación Provincial, ${ }^{24}$ prefirieran desempeñarse en las Cortes porque les permitía ampliar su campo de acción. Es posible también, como señala Virginia Guedea, que en esta decisión pesaran otras consideraciones: las derrotas insurgentes habían fortalecido un régimen colonial empeñado en cerrar las vías de participación política a los americanos autonomistas, y las autoridades coloniales los vigilaban de cerca. ${ }^{25}$ Los Guadalupes

22 Benson, Diputación, pp. 36-37.

23 Ibid., p. 36.

${ }^{24}$ La Diputación Provincial de Nueva España quedó integrada en 1814 por Félix María Calleja, jefe político; Ramón Gutiérrez Mazo, intendente; José Ángel Gazano, diputado por México; Pedro Acevedo y Calderón, por Querétaro; Juan Daza y Artanzo, por Tlaxcala; Juan Bautista Lobo, por la provincia de México en sustitución del diputado por Oaxaca, e Ignacio Gracia Illueca en sustitución de José María Fagoaga. Benson, Diputact6n, p. 38, n. 62.

${ }^{25} \mathrm{El}$ hecho que Del Cristo y Fagoaga fueran primero electos a la Diputación Provincial y 


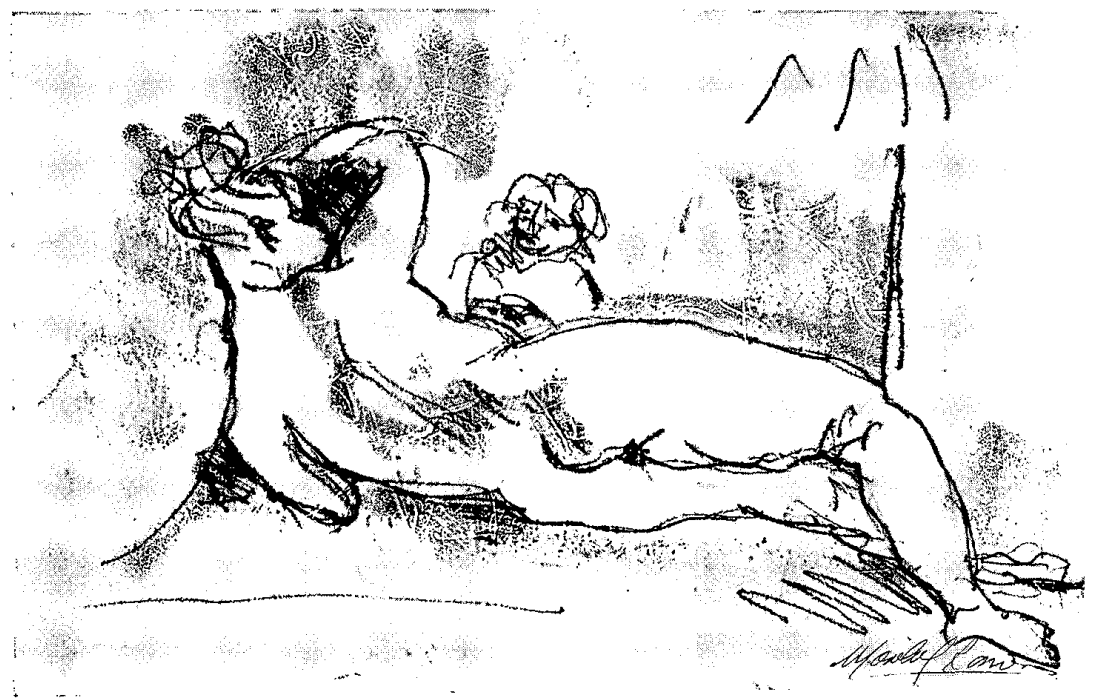

continuaron ganando importantes cargos de representación popular, pero apenas alcanzaron a funcionar por un mes, puesto que el 11 de agosto de 1814 llegó a Nueva España el real decreto que derogó la Constitución de 1812 e invistió a Fernando VII con poderes absolutos. ${ }^{26}$ Bajo estas circunstancias se recrudeció la represión virreinal.

Calleja tenía pruebas en contra de los principales miembros de Los

poco después como diputados a Cortes muestra la capacidad de Los Guadalupes para aprove. char los tiempos políticos. De haberse quedado en la Diputación Provincial sólo habrian estado en funciones por un mes, así Los Guadalupes también ampliaban su tiempo de acción. Guedea, Busca, 1992, pp. 306-308.

26 Benson, Diputación, 1980, p. 39.
Guadalupes desde 1813 pero, debido a que los preceptos constitucionales rodeaban con amplias garantías a los delincuentes, se había visto imposibilitado de actuar. ${ }^{27}$

En una carta al ministro de Gracia y Justicia explicaba que las elecciones al Ayuntamiento constitucional, diputados a Cortes, y vocales de la Junta Provincial habían recaído en los rebeldes, "singuralizando las circunstancias del regidor don Ignacio Adalid, y el oidor honorario José María Fagoaga, electos para individuos del Congreso". Agregó que a Adalid se le había sometido a

27 Unicamente había podido enjuiciar al Dr. Alcalá. Los artículos 289 a 308 de la Constitución de Cádiz detallan las garantías que rodeaban al ciudadano en lo relativo a la administración de justicia en lo criminal. 
proceso "como verdadero traidor, miembro de una diabólica junta, establecida en esta capital bajo el nombre de Guadalupes, y uno de los mayores criminales de esta insurrección". ${ }^{28}$

En otra carta Calleja reconocía ante el mismo ministro que no había podido proceder en contra de los rebeldes puesto que

entre los americanos domina una especie de francmasonismo, digámoslo así, que los pone a seguro de toda averigua. ción en tratándose de asuntos de infidencia. Todos están unidos; caminan a un fin; obran por iguales principios y no se descubren jamás. Los europeos que muchas veces podrian atestiguar los hechos, se retraen de hacerlo, porque temen que sin ser de ninguna utilidad su atestación, porque no ven cas. tigos y penas, sólo les serviría para contraerse enemigos y quedar en descubierto. ${ }^{29}$

Calleja en una comunicación al ministro de Gobernación de Ultramar detalló las dificultades con las que tropezaba. Cobijados por el Ayuntamiento de México, Los Guadalupes nombraban a los jueces de letras y en sus manos estaban "la policía y la averiguación de los delitos", así, resultaban

del mismo partido el reo, el juez, el escribano y el testigo; de manera que estando en esta parte ceñidas las operaciones de los jueces a los términos de la LIII.

28 De la Torre Villar, Guadalupes, 1966, p.

29 "Carta del virrey de Nueva España, don Félix María Calleja, al ministro de Gracia y Justicia, 30 de julio de 1814", ibid., p. 131. ley, jamás se dará el caso de condenar a ningún delincuente de dicha clase. ${ }^{30}$

Pronto cambiaron las circunstancias. Los realistas obtuvieron las pruebas que les faltaban para abrir los procesos en contra de Los Guadalupes puesto que el archivo del Congreso de Chilpancingo pasó a manos de los realistas en la batalla de Tlacotepec, y poco después Rayón perdió toda su correspondencia en la batalla de Zacatlán. ${ }^{31}$ Por si fuera poco, en abril de 1813 se había hecho pública la ruptura entre los vocales de la Junta, y Rayón expidió un bando en el que manifestaba que Liceaga y Verduzco quedaban suspendidos como vocales. 32

El fiscal, coronel Vicente Ruiz, a pesar de contar con las pruebas fehacientes para sentenciarlos, señalaba que sería conveniente que se les indultara puesto que se hallaban complicados un "sinnúmero de personas de las principales clases del Estado y formando entre ellas corporaciones respetables enteras". 33

Efectivamente, muchos fueron indultados por la real orden del 1 de junio de 1814 que estableció que se libertara a las personas "de quien pru-

30 "Comunicación de don Félix María Catleja al ministro de Gobernación de Ultramar, 22 de junio de 1813", ibid., p. 39.

31 Ibid., p. LXVI.

32 Guedea, Busca, 1992, p. 238.

33 El fiscal guardaba especiales miramientos con los miembros de las diversas corporaciones: José María Fagoaga, Jacobo de Villaurrutia, el conde de Medina (alcalde constitucional), Ángel Vargas Machuca (ex gobernador de indios y regidor constitucional), el Lic. Márquez (síndico constitucional), Ignacio Orellana (elec- 
dentemente se espere que no puedan alterar la tranquilidad y orden público", y que se procesara a los tumultuarios y sediciosos. ${ }^{34}$ Entre estos últimos estaban las principales cabezas de Los Guadalupes, sentenciados en 1815.

El cacique indígena y regidor del Ayuntamiento, Francisco Antonio Galicia, fue condenado a ocho años de presidio en las Islas Marianas. Murió antes de embarcarse. ${ }^{35}$ José María Fagoaga fue hecho prisionero y en 1815 se embarcó rumbo al destierro. Sus bienes fueron incautados. Poco después, Jacobo de Villaurrutia siguió el mismo destino. ${ }^{36}$ El licenciado Juan Bautista Raz y Guzmán fue encerrado en la Cárcel de Corte. En 1816 José Ma. riano Sardaneta era condenado al destierro, pero el marqués logró retardar su salida a España y permaneció en Veracruz hasta 1820. Adalid también fue enjuiciado, pero durante el proceso se descubrió el doble juego que había sostenido al apoyar simultáneamente a las tropas realistas e insurgentes, lo que naturalmente le resultó negativo en ambos bandos. En 1815 salió rumbo a la península. ${ }^{37}$

tor del Ayuntamiento de México), Ignacio Ada. lid (regidor constitucional), Carlos María de Bustamante (elector del Ayuntamiento), Pbro. Alejo Nozagaray (elector), Pbro. Tomás Ximénez Caro (sobrino del conde de Medina), el Lic. Manuel Cortázar, Ramón Alarcón, Tomás Cas. tillo (teniente). "Comunicación de don Félix María Calleja al ministro de Ultramar, 22 de junio de 1813. Anexo $2^{n}$, De la Torre Villar, Guadalupes, p. 41.

34 "Real orden de 10 de junio de 1814 ", $t$ bid., 1966, pp. 151.152.

35 Guedea, Busca, 1992, pp. 316-321.

36 Zárate, Guerra, 1969, p. 466.

37 Guedea, Busca, 1992, pp. 324 y 332-336.
La sociedad de Los Guadalupes quedó sumamente debilitada. Sin embargo, sus miembros continuaron apoyando aunque de manera no tan efectiva a Francisco Javier Mina.

Ernesto de la Torre Villar sugiere que Los Guadalupes no se extinguieron sino que cambiaron de táctica y adoptaron como base organizativa la masonería, puesto que les resultaba inútil mantener un grupo aislado y expuesto al peligro si se podía contar con una vasta organización internacional que apoyaba los movimientos autonomistas y que presentaba elementos comunes: organización secreta, juramentos de sumisión, jerarquización y eficiencia. ${ }^{38}$

Nuestros actores políticos regresaron a la palestra pública en 1820 cuando se restableció el régimen constitucional por el triunfo del movimiento liberal de Riego. En Madrid se instaló la Junta Consultiva Provisional que decretó la liberación de los presos por motivos políticos o religiosos. El 10 de marzo Fernando VII juró la Constitución y convocó a las Cortes. En consecuencia, las autonomistas desterrados retornaron a la capital de Nueva España con los cargos que desempeñaban en 1814. José María Fagoaga regresó como alcalde honorario de la Real Audiencia, mientras Sardaneta volvía

38 De la Torre Villar, Guadalupes, 1966, p. LXXIII, Guadalupe Jiménez Codinach señala que algunos de ellos se refugiaron en Londres y en 1814 y 1815 se empezaron reunir en Ja Logia 7 de los Caballeros racionales, Xavier Mina, Servando Teresa de Mier, Francisco y José María Fagoaga, Jacobo Villaurrutia, Juan O'Donojú, y posiblemente Lucas Alamán, Jiménez Codinach, "Introducción", 1987, pp. 32 y 41. 
de Veracruz a la capital y Sánchez de Tagle de la península. Así, los miembros de la Junta Provincial de Censura de 1813 fueron convocados para prestar juramento el 21 de junio de 1820. Sin embargo, sólo concurrieron tres de sus miembros originales: Pedro González, Francisco Manuel Sánchez de Tagle y Agustín Villanueva. Entre los ausentes estaba José María Fagoaga que no pudo reintegrarse porque ocupaba otro cargo público: vocal de la Diputación Provincial. Pese a ello, la Junta de Censura otra vez quedó en manos de ex Guadalupes, siendo integrada por Tagle, el marqués de San Juan de Rayas, y por Francisco Fagoaga. 39

Nuestro grupo también insertó a sus miembros en los órganos de representación con medios similares a los utilizados en 1813 y 1814 . Fueron electos para conformar el Ayuntamiento de 1820: Adalid, Benito José Guerra (también antiguo Guadalupe), Sánchez de Tagle y Zozaya. ${ }^{40}$

La Diputación Provincial también fue controlada por ex Guadalupes y pronto se convirtió en un órgano clave para la causa de los independentistas, sin desacatar la autoridad del virrey; ${ }^{41}$ continuó de manera un tanto

${ }^{39} \mathrm{Neal}$, "Libertad", pp. 117-118. Esta autora señala que participaron José Mariano Zandaneta [sic] y el marqués de Rayas sin percatarse que se trata de la misma persona.

40 lbid., p. 378.

41 La Diputación Provincial tuvo un periodo (del 30 de septiembre de 1820 hasta el 26 de febrero de 1821) que se caracterizó por las relaciones armónicas que sostuvo con el virrey Apodaca, aunque comenzó a mostrar signos de una voluntad de autonomía política, ibid., pp. 17 . $18,22$. velada, apoyando el avance militar de Iturbide a la ciudad de México. Por ejemplo, Apodaca solicitó que se derogara la libertad de imprenta, iniciativa que recibió una rotunda negativa por parte de la Diputación. Ésta señaló que a pesar de los abusos que se habían registrado ni el mismo rey podía suprimirla puesto que estaba garantizada por la Constitución. ${ }^{42}$ Sin embargo, dos días después el virrey suspendió esta libertad y la Diputación envió una representación a las Cortes en la que expresó su desacuerdo. Posteriormente, García Illueca y Fagoaga exigieron la liberación de ciertos reos militares. ${ }^{43}$ Los mismos diputados apoyaron al Ayuntamiento de Puebla que se rehusaba a pagar un préstamo forzoso para obras de fortificación. Los ex Guadalupes señalaron que "es un abuso y la Diputación Provincial jamás podrá autorizarlo"; puesto que las obras de fortificación y defensa no estaban comprendidas entre las atribuciones de ese cuerpo, indicaron que en todo caso, este pago lo debía hacer la Hacienda Nacional. ${ }^{44}$ Más aún, la Diputación prohibió la leva que ordenó Apodaca ante la cercanía del Ejército Trigarante al Valle de México. La Diputàción consideraba que la leva era una medida que "ataca directamente la libertad individual, objeto primario de nuestra constitución". Asimismo mostraron su desacuerdo por la requisición ordenada en la ciudad

42 Sesión 86, 31 de mayo de 1821 , Herrejón, Actas, 1985, p. 325.

${ }^{43}$ Sesión extraordinaria 4, 16 de junio de 1821, ibtd., pp. 331-332.

${ }_{44}^{4}$ Sesión extraordinaria 8,26 de junio de 1821, ibtd., p. 339. 
de México de monturas y armas puesto que violaba "directamente la propiedad del ciudadano". 45

Corrió un rumor en el sentido de que la Diputación sería suprimida por su oposición sistemática a las medidas que Apodaca buscaba llevar a cabo para detener el avance trigarante, pero los diputados continuaron sesionan$\mathrm{do}^{46}$ y se convirtieron en efectivos mediadores, primero entre Apodaca y Francisco Novella, quien dio un golpe de Estado al primero obligándolo a entregar el mando, hecho que desconoció la Diputación. ${ }^{47} \mathrm{El} 31$ de agosto esta corporación reconoció los Tratados de Córdoba establecidos entre Iturbide y $O^{\prime}$ Donujú ${ }^{48}$ y nuevamente fungió como un exitoso mediador que logró que Novella los aceptara el 14 de septiembre.

La Diputación cumplió con dos últimas e importantes misiones. Negoció con Iturbide a través de una comisión (integrada por Fagoaga, Lobo,

45 Ibid., p. 338.

46 Ibid., pp. 17-18, 22.

${ }^{47} \mathrm{El} 5$ de julio las fuerzas expedicionarias obligaron a renunciar al virrey Apodaca haciéndose cargo Francisco Novella. Al día siguiente seis diputados (Fagoaga, Alcocer, Lobo, Barque. ra, Mimiaga e Illueca) fueron convocados por el intendente para darles a conocer el hecho. En nombre de la Diputación Provincial respondie. ron que la dimisión era nula, "porque lo primero [...] fue violenta; lo segundo, porque no hay facultades de vuestra excelencia para entregar el mando a la persona que le haya parecido, sino a los que designa la ley en caso de imposibilidad". De esta manera, los diputados también desconocían la designación de Francisco Nove1la. Sesión extraordinaria 11, 6 de julio de 1821, ibid., pp. 344-345.

48 Sesión extraordinaria 18,31 de agosto de 1821, ibid., p. 363.
Alcocer y García Illueca) lo relativo a su marcha triunfal por la ciudad de México y, lo que era más importante, la designación de los miembros de la Junta Suprema de Gobierno que se encargaría interinamente de la administración del país y el juramento que ésta prestaría ante la "representación nacional". 49

Formalmente la función negociadora que recayó en esta comisión se debió a que la Diputación Provincial era el cuerpo que representaba al conjunto de Nueva España. En un sentido informal, podría aventurarse que también se debió a la estrecha relación que Fagoaga guardaba con Iturbide desde tiempo atrás. El historiador Lucas Alamán indica que José María, incluso, participó en la redacción del Plan de Iguala. ${ }^{50}$

El 27 de septiembre la Diputación Provincial de Nueva España recibió a Iturbide en la escalera de Palacio Nacional, concluyendo sus funciones y entregando el poder a la Suprema Junta Provisional Gubernativa.

En síntesis, los liberales novohispanos, y entre ellos Los Guadalupes, aprovecharon los espacios políticos que abrió la Constitución de Cádiz: los ayuntamientos constitucionales, las diputaciones provinciales y las Cortes. Estas tres instancias de representación se retroalimentaban reactivando la participación política. Al Ayuntamiento correspondía vigilar por la seguridad de las personas y bienes de los vecinos, así como la preservación

49 Sesión extraordinaria 22,24 de septiembre de 1821, tbid., pp. 369-370.

${ }^{50}$ Alamán, Historia, 1985, vol. v, p. 326. 
del orden público. ${ }^{51}$ La Diputación estaba encargada de que se establecieran ayuntamientos en los pueblos que cumplieran los requisitos previstos, repartir la recaudación de las contribuciones que los pueblos hacían a la corona y dar a conocer a las cortes los abusos que el gobierno cometiera en la administración de rentas públicas y las infracciones a la Constitución que se cometieran en las provincias, arma jurídica que Los Guadalupes aprovecharon con representaciones en contra de las autoridades virreinales. ${ }^{52}$ Las Cortes fungieron como el poder legislativo del conjunto del imperio, tenían amplísimas facultades fiscales, militares, administrativas, convirtiéndose en un importante candado que buscaba impedir que el rey se extralimitara en el ejercicio de sus funciones. ${ }^{53} \mathrm{~A}$ los independentistas el acceso a las Cortes les permitió, además, vincularse

51 Otras facultades de los ayuntamientos conforme al artículo 321 constitucional eran la administración e inversión de los caudales munici. pales, la recaudación de contribuciones, cuidar de las escuelas de primeras letras, encargarse de los caminos y calzadas, así como de los bienes agrícolas municipales y promover la agricultura, la industria y el comercio de la localidad. "Constitución", en Tena, Leyes, 1988, p. 97.

52 Artículo 335 de la Constitución gaditana, ibid., p. 98; Herrejón, Actas, p. 325.

53 Entre las facultades de las Cortes destacan las siguientes: resolver las dudas en la sucesión a la corona, fijar a propuesta del rey las fuerzas de mar y tierra, conceder o negar la admisión de tropas extranjeras, decretar la creación y supresión de plazas en los tribunales, fijar los gastos de la administración pública y establecer anualmente las contribuciones e impuestos, disponer lo relativo a la administración de bienes nacionales y proteger la libertad política de la im. prenta. Artículo 131, en Tena, Leyes, 1988, p. 120. con los diversos territorios españoles. De manera que la Constitución española abrió la participación política criolla, pero al mismo tiempo sentó las bases para permitir la independencia novohispana dentro de los límites de la institucionalidad.

Cabe destacar que a pesar de que la Constitución de Cádiz se mantuvo como un modelo a seguir e incluso se mantuvo vigente hasta 1824 , los independentistas (y si hemos de creerle a Alamán, específicamente José María Fagoaga) introdujeron, a través del Plan de Iguala, importantes modificaciones al orden institucional. Dicho Plan amplió la ciudadanía de manera que "todos los habitantes de Nueva España sin distinción alguna de europeos o africanos, ni indios, son ciudadanos de esta monarquía con opción a todo empleo, según su mérito y sus virtudes". El texto constitucional gaditano había negado la ciudadanía a las castas y a los sirvientes, y exigía la prueba de hidalguía para desempeñar un cargo público. El Plan de Iguala era también un documento que llamaba a la reconciliación entre europeos, americanos e indigenas como "la única base sólida en que puede descansar nuestra común felicidad" y un llamado a mantener el orden interior con "horror a cualquier movimiento turbulento".

La capacidad de Los Guadalupes para insertar a sus miembros en los órganos de representación se explica porvarias razones: las redes de sociabilidad que les hizo posible articular a los diversos sectores sociales y su eficiencia organizativa, sobre cuyo funcionamiento se carece de detalles. En lo que se refiere a la base electoral que 
los sustentaba, ésta no podrá conocerse hasta que se llevan a cabo mayores investigaciones sobre la relación entre las empresas familiares de la elite y su electorado.

\section{La Junta Provisional Gubernativa}

Los Tratados de Córdova preveían la manera en que debería gobernarse la nación mientras llegaba un miembro de la familia real para reinar. Una junta entre sus miembros elegiría un presidente y una regencia compuesta por tres personas en las que se depositaba el poder ejecutivo. La Junta se convirtió en el cuerpo legislativo, auxiliar y consultivo de la regencia. Sus funciones específicas eran llevar a la práctica el Plan de Iguala en todas sus partes, vigilar la marcha de la administración pública sin introducirle modificaciones, y convocar a un congreso que diera forma a la constitución del Imperio Mexicano, mientras tanto regiría la Constitución de Cádiz. ${ }^{54}$

La Junta fue designada por Iturbide con la activa participación de la comisión de la Diputación integrada por ex Guadalupes. Se formó con base en corporaciones y estamentos: diputados, regidores, militares y eclesiásticos. Los representantes de la nación eran exclusivamente los notables afectos a la independencia que según los Tratados de Córdoba serían

los primeros hombres del imperio, por sus virtudes, por sus destinos, por sus

54 "Tratados", en Matute, México, 1992, pp. 231-232. fortunas, representación y conceptos, de aquellos que estén designados por la opinión general, cuyo número sea bastante considerado para que sus luces aseguren el acierto en sus determinaciones. 55

A la junta se integraron Sardaneta, Tagle, Fagoaga quienes cumplían ampliamente con los requisitos: su virtud había sido demostrada con el apoyo que brindaron a Iturbide, pertenecían a familias nobles y sus fortunas continuaban siendo las más importantes del reino. Otros ex Guadalupes también fueron designados, lo que se tradujo en una oportunidad para que el grupo político se rearticulara y creara nuevas alianzas; trabajaban juntos García Illueca, Manuel de Heras Soto, Juan Bautista Lobo, ex regidor del Ayuntamiento de Veracruz, y Juan Obregoso, coronel de los Ejércitos Nacionales.

Este núcleo estableció alianzas con otros miembros de la Junta lo que les permitió tener acceso a casi todas las comisiones: Reglamento Interior de la Junta, Hacienda, Relaciones Exteriores, Guerra, Justicia y Asuntos Eclesiásticos, y convocatoria a la casa Borbón para ofrecerle la corona mexicana. La única comisión en la que no participaron fue la de Relaciones Interiores, cuya importancia sería equivalente a la comisión legislativa de Gobernación de nuestros días.

El primer acto que la Junta llevó a cabo fue la firma del acta de independencia. En este documento naturalmente se declaraba que la nación era "soberana e independiente de la anti-

55 Ibid., p. 231. 


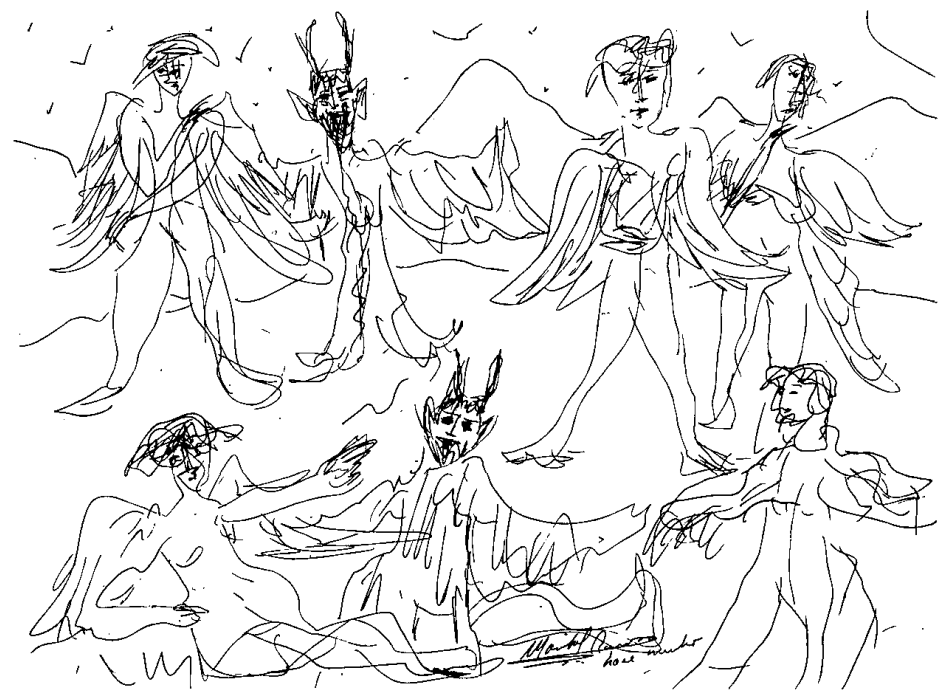

gua España" y afirmaba que "la nación mexicana que, por trescientos años, ni ha tenido voluntad propia, ni libre el uso de la voz, sale hoy de la opresión que ha vivido". 56

En el orden administrativo el primer problema que la Junta tuvo que resolver fue la solicitud de algunas autoridades eclesiásticas para abrir los noviciados y profesiones, suspendidos por las Cortes. La Diputación Provincial de México solicitó que se reincorporaran las comunidades de los hospitalarios, suspendidas en la capital, y la Compañía de Jesús.

La discusión de esta solicitud puso al descubierto al "partido liberal" (poco

${ }^{56} \mathrm{Se}$ reproduce integramente en Tena, Leyes, 1988, pp. 122-123. después conocido como "borbonista") que encabezaba Fagoaga, y al que pertenecían sus antiguos correligionarios Tagle y el conde de Heras. Los tres eran partidarios de las reformas eclesiásticas que las Cortes habían introducido, puesto que se inclinaban en favor de que el nuevo Estado mantuviera el control sobre la Iglesia conforme a la tradición hispánica.

A Fagoaga lo seguían los militares sobre quienes tenía una gran influencia, y se le unieron los abogado de la Junta. En el partido opuesto se encontraban el clero y títulos, los iturbidistas incondicionales y hombres como Alcocer que a la sazón era presidente, firme en sus principios de liberalismo político, pero que no quería que se tocaran asuntos religiosos porque de- 
pendian directamente de Iturbide y votaba conforme a éste. ${ }^{57}$ Lucas Alamán afirma que:

el terreno era muy desventajoso para los liberales, supuesto lo que habían precedido y el objeto que había tenido la revolución: así no entraron a la contienda a descubierto, sino defendidos por el atrincheramiento que les presentaba el carácter provisional de la Junta, que conforme al Tratado de Córdoba no debía de ocuparse sino de lo que podía calificarse de urgente. ${ }^{58}$

Fagoaga encabezó la discusión, y el nuevo grupo político obtuvo su primer éxito al declararse que los noviciados, profesiones y prelacías se reabrirían, pero lo concerniente a los jesuitas y hospitalarios se posponía a las deliberaciones del Congreso y al restablecimiento del Real Patronato Indiano. 59

El problema más grave al que se enfrentó la Junta fue la reforma del ramo hacendario. De acuerdo con su diagnóstico:

Quedó el Imperio al disolverse el antiguo gobierno, sin erario; obstruidas las fuentes de la riqueza pública; alterados los rumbos todos los giros; extraviada la opinión en millares de puntos; recargados los pueblos de contribuciones gravosísimas, y acostumbrados de consiguiente a defraudarlas; sin ningún sistema de hacienda ni administración; sin seguridad de la adhesión o aversión de los empleados públicos.

57 Olavarría y Ferrari, México, 1967, vol. rv, p. 31; Alamán, Historia, vol. v, p.p. 389-390.

58 Ibid., p. 382.

59 Ibid., pp. 382-387; Olavarría y Ferrari, México, 1967, vol. rv, p. 32.
Por si fuera poco, los gastos civiles y militares habían crecido enormemente por la guerra e Iturbide repartía generosos premios y recompensas. Los gobernantes no podian cobrar los antiguos impuestos por "ruinosos, mal combinados y contrarios a la opinión e interés general", pero tampoco podían suprimirlos del todo. El antiguo estanco del tabaco, la fuente de ingresos "más valiosa y productiva en el sistema antiguo", estaba cargado con enormes deudas y no se contaban con las materias primas necesarias para los campos de labor. Aunque los miembros de la Junta se inclinaban por la implantación de un sistema hacendario de contribución directa, no les escapaba que el naciente Estado no tenía los medios coercitivos para recaudar los impuestos. ${ }^{60}$ Es de sobra conocido que fue hasta 1867 cuando se adoptó un sistema fiscal liberal, y no fue sino hasta la década de 1890 cuando se aliviarian plenamente las dificultades financieras del Estado. 61

Fagoaga, Tagle, Antonio de Gama y Córdoba y el conde de Heras y Soto junto con su aliado, Juan Francisco de Azcárate, formaron la comisión que realizó el estudio sobre la esclavitud en el Imperio. El dictamen era una fiel expresión de estos hombres que provenían de una sociedad estamentaria al tiempo que hacían profesión de una profunda fe liberal, y sin embargo, querían modelar una sociedad nueva, pero sin introducir cambios rápidos ni

${ }^{60}$ Suprema Junta Nacional Gubernativa, Diario, 1822, pp. 4 y 5.

61 Para mayores detalles véase Carmagnani, Estado, 1994. 
drásticos que terminaran por desarticularla.

El dictamen se promulgó el 24 de octubre de 1821, como una furiosa condena a la esclavitud. ${ }^{62}$ No en balde tenían como antecedentes jurídicos los Elementos constitucionales de Ignacio López Rayón (1811) y la Constitución de Apatzingán (1814) que habían abolido. Los comisionados rechazaban la esclavitud igualándola al periodo colonial y, embriagados por la empresa de construir una nueva y mejor sociedad, afirmaban que la naciente nación mexicana

es la mansión de la humanidad, de la libertad, y de la moderación: ¿podrá permitir entren a él personas miserables que gimen bajo el yugo de la servidumbre? Lejos de nosotros semejantes ejemplares infelices: en el Imperio que va ser el seno de la abundancia, la paz y la felicidad no debe de percibirse el sollozo del esclavo. ${ }^{63}$

Ante la disyuntiva que, por una parte, les presentaban las ideas ilustradas y los principios jusnaturalistas y, por la otra, el principio liberal de protección a la propiedad privada, se buscó dar forma a una legislación que progresivamente condujera a la manutención de los esclavos. Pero la abolición de la esclavitud no era un problema de fácil resolución. En el territorio del Imperio Mexicano en 1821, según esta comisión, había más de 3000 esclavos, y ordenar su liberación significaba atentar en contra de "la propiedad de los dueños". Por ello proponían

62 Suprema, Dictamen de la comisión de esclavos, 1821, p. 1.

63 lbid., p. 4. que los ayuntamientos comprarían su libertad; se prohibió la introducción de esclavos, y aquellos que fuesen introducidos al imperio, al tocar suelo mexicano recuperarían su libertad. Los hijos de los esclavos nacidos a partir del 24 de febrero de 1821 se consideraban hombres libres. ${ }^{64}$

Conforme a los principios liberales también se prohibió cualquier forma de trabajo forzado o personal, ya fuese de indios o presos. El dictamen era contundente, abolía el trabajo personal y convertía a los indios en trabajadores libres asalariados. ${ }^{65}$

Los trabajos de la Junta desde un inicio fueron obstaculizados por un fuerte conflicto con la Regencia (integrada por el mismo Iturbide como presidente, Manuel Bárcena, el obispo de Puebla Joaquín Pérez, Manuel Velázquez de León e Isidro Yáñez). El núcleo de la tensión surgía de la yuxtaposición de las facultades que se confirieron a los dos órganos de gobierno. La Junta debía ser el cuerpo legislativo, y al mismo tiempo consultivo y auxiliar de la Regencia. Pero sus facultades legislativas se limitaban a los casos en que no hubiera ley o que ésta contraviniera la independencia, y sólo en aquellos casos que no se pudiera esperar a la reunión del Congreso. ${ }^{66}$

64 Ibid., p. 7.

65 A la letra se estableció que "el servicio personal de los ciudadanos indios queda abolido aun cuando voluntariamente quieran pres. tarlo, y los que lo reciban, de cualquier estado y condición que sean, serán castigados con las penas prevenidas por las leyes y pagarán al inte. resado la cantidad en que se aprecie el servicio", ibid., pp. 8-9.

66 Suprema, Diario, 1822, p. 4. 
El grupo borbonista sin duda sobrepasó sus facultades y luchó por el respeto a los derechos del hombre y por limitar las excesivas atribuciones que el Plan de Iguala y los Tratados de Córdoba otorgaban a Iturbide. En la misma Junta se formó un partido que se opuso sistemáticamente a Iturbide, lo integraban, según el testimonio de Lorenzo de Zavala,

don José María Fagoaga, personaje conocido por sus padecimientos, por su adhesión a la Constitución española, por sus riquezas y por su buena moral; don Francisco Sánchez de Tagle, igualmente estimado por sus luces y otras cualidades; don Hipólito Odardo y don Juan Obregozo [sic]. ${ }^{67}$

La libertad de imprenta había sido una de las grandes preocupaciones para este grupo desde 1812, cuando Fagoaga y Tagle militaban en Los Guadalupes. A pesar de los obstáculos que opuso la Regencia se logró que se aprobara la ley "para que ese precioso derecho del ciudadano fuese asegurado y sus abusos pudiesen reprimirse con oportunidad". ${ }^{68}$ No se toleraba una libertad irrestricta. Fagoaga apoyó que se restableciera la Ley de Imprenta de 1820,69 pero la Regencia la modificó con el decreto del 6 de octubre de 1821, que estableció que los impresores estaban obligados a enviar gratuitamente ejemplares de los periódicos e impresos a los jefes políticos y a los comandantes generales de las provin-

\footnotetext{
67 Zavala, Ensayo, 1985, vol. 1, p. 101.

68 Suprema, Diario, p. 7.

69 Neal, "Libertad", 1985, p. 119.
}

cias para que éstos los calificaran..$^{70} \mathrm{En}$ respuesta la Junta Gubernativa el 19 de diciembre de 1821 estableció la Junta de Protección de la Libertad de Imprenta para proteger a los autores del excesivo celo de los censores. ${ }^{71}$

En lo que se refiere a la tensión entre poderes, el conflicto entre Iturbide y el grupo borbonista se presentó con especial encono en octubre de 1821 , cuando Iturbide fue nombrado presidente de la Regencia cuando ya lo era de la Junta. Fagoaga señaló que con ello se perdía la distinción entre los poderes ejecutivo y legislativo. Propuso que se diera "a Iturbide la precedencia, es decir, la preferencia en el lugar, asiento y demás actos honoríficos", y que se nombrara a otra persona para que presidiera la Junta. En efecto, así se hizo.

Entre octubre y diciembre de 1821 estalló un segundo conflicto, debido a que se elaboraron tres reglamentos para la convocatoria al Congreso Constituyente. La regencia propuso que el Congreso se integrara con dos cámaras, la alta, en que la representación estamentaria correspondería a la cámara alta con el clero, el ejército y las provincias; y la cámara baja que estaría formada por representantes de los ciudadanos elegidos a razón de un diputado por cada 50000 habitantes. Iturbide se inclinó también por el bicamerismo pero con elección direc-

${ }^{70}$ Gaceta Imperial Extraordinaria de Méxi. co, 17 de octubre de 1821 . Este decreto fue refrendado por la Regencia el 6 de octubre y pro. mulgado por el jefe político de México, Ramón Gutiérrez del Mazo, el 16 de octubre de 1821.

71 López, Carlos, 1991, pp. 15.17; Alamán, Historia, 1985, vol. v, pp. 407.408 . 


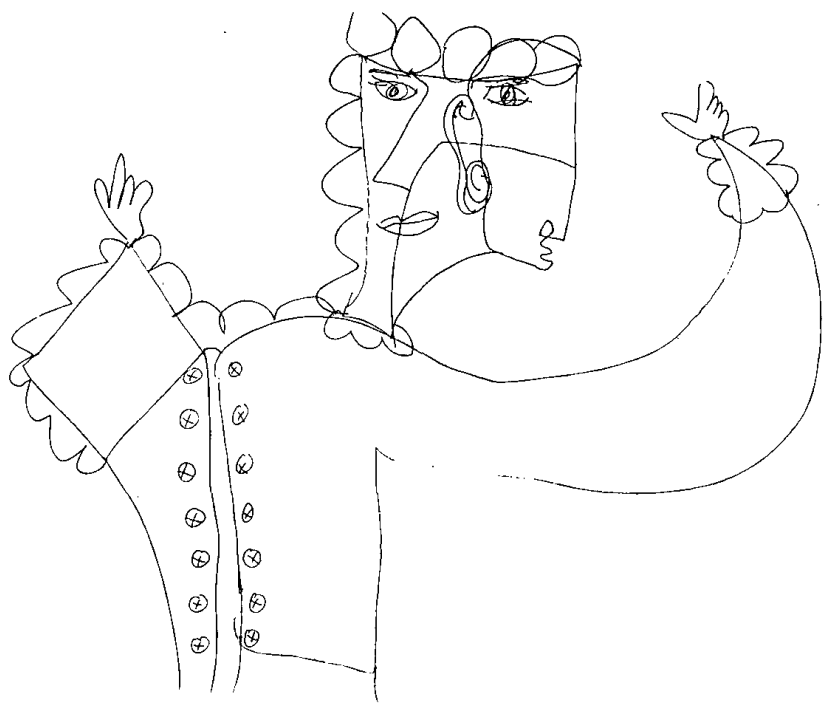

ta. ${ }^{72}$ Los borbonistas preferían que se mantuviese el articulado de la Constitución gaditana, un congreso formado por una sola cámara de elección popular y voto indirecto; para ser diputado bastaban la ciudadanía y ser mayor de treinta años. ${ }^{73}$

En esta ocasión los borbonistas perdieron la batalla y se promulgó la convocatoria de Iturbide con algunas modificaciones. ${ }^{74}$ La convocatoria fue redactada bajo un horizonte estamentario. Se elegía de manera proporcional representantes por clases y ofi-

72 Tena, Leyes, 1988, p. 120.

73 Artículo 91 de la Constitución Política de la Monarquía Española, ibid., p. 70.

${ }^{74}$ Alamán, Historia, 1985 , vol. v, pp. 370 $371,392$. cios: eclesiástico, militar, abogado o letrado, minero, título y mayorazgo. De esta manera, a las antiguas corporaciones coloniales, incluyendo la nobleza (que se representaba a través de la categoría de título y mayorazgo), se agregaba una nueva, la de los militares, misma que se había formado durante la lucha armada.

La convocatoria al Constituyente expresaba dos proyectos políticos de nación, opuestos. En los reglamentos que elaboraron Iturbide y la Regencia se buscaba representar en la cámara alta a los actores colectivos de la sociedad; cada diputado representaba un mandato imperativo de su corporación. Por ello, los liberales calificaron la conformación del Constituyente como "una parodia ridícula de los 
estamentos de España o de los Estados Generales de Francia". 75

Los borbonistas, al propugnar por la igualdad del ciudadano ante la ley, buscaban la desaparición de los fueros y privilegios de los que gozaba cada corporación. El sistema representativo popular suponía que los mandatarios eran representantes del conjunto de la ciudadanía, aunque su elección correspondiera a una circunscripción territorial.

La participación del grupo borbonista y la actuación de la propia Junta fue gravemente criticada. Lorenzo de Zavala, a la sazón furibundo iturbidista, señaló que la Junta había sido dominada por los

doctrinarios, esos hombres de sistema que creen infalibles sus principios, y lo que es peor, que hacen tan mala aplicación de ellos. Fagoaga, Odardo, Tagle, el conde de Heras, y otros hombres como éstos, que habían leído obras de política, $\sin$ haber visto nunca la práctica de gobernar, tenían la verbosidad para hacer callar a los que, aunque sintiesén lo contrario que ellos, no podian contestarles. ${ }^{76}$

Con estas afirmaciones Zavala buscaba descalificar el indudable liderazgo que los borbonistas habían desempeñado en la Junta, el que descansaba precisamente en su experiencia de gobierno adquirida en los cargos virreinales.

La Junta también fue criticada por haberse atribuido mayores facultades que las que le otorgaba el Plan de

75 Zavala, Ensayo, 1985, vol. I, p. 105.

76 Ibid., p. 104 .
Iguala y por haber retardado la convocatoria al Congreso Constituyente. ${ }^{77}$ En efecto, ellos mismos reconocieron que habían tratado de sentar las bases de un Estado nuevo. ${ }^{78}$ Odardo, Guridi y Alcocer y Fagoaga fueron electos diputados al Constituyente, a pesar de las críticas y los conflictos que los borbonistas enfrentaron con Iturbide y con el partido republicano que entonces empezaba a formarse. ${ }^{79}$

\section{El CONSTITUYENTE}

En las labores que el Congreso Constituyente desempeñó en los primeros meses de 1822 destacan los elementos de continuidad respecto a la Constitución de Cádiz: se estableció la religión católica como la única tolerada y se adoptó como sistema de gobierno la monarquía constitucional. Las novedades fueron el reconocimiento de los Tratados de Córdoba y el llamamiento de un príncipe de la Casa Borbón para ocupar el trono mexicano. En el juramento, que los diputados presentaron el 24 de febrero de 1822 , se mencionaban dos principios liberales de inspiración gaditana por los que arduamente habían luchado los borbonistas en la Junta Gubernativa: la separación de poderes y la igualdad de derechos civi-

77 Ibid., p. 105

${ }^{78}$ Suprema, Diario, 1822, p. 10.

79 Las credenciales de Odardo y Fagoaga fueron sometidas a discusión por la propia Junta, ya que no podían representar a dos corporaciones al mismo tiempo, sus credenciales terminaron por aceptarse. Para mayores detalles véase López, Carlos, 1991. 
les de todos los habitantes del Imperio, cualquiera que fuese su origen.

A instancias de Fagoaga se declaró que la soberanía residía en el Congreso. ${ }^{80}$ La distinción era relevante en la medida en que de acuerdo con la teoría constitucional decimonónica el pueblo delegaba completamente su soberanía por una única ocasión en el Constituyente que tenía la misión trascendental de dar forma a la nación y quedaba libre de cualquier pacto $o$ compromiso que antes se hubiera establecido con otra nación o con el pueblo. ${ }^{81}$ No obstante, el grupo borbonista desde las primeras sesiones del Congreso se orientó a fijar las bases para establecer una monarquía constitucional y "ninguno en aquel momento osó pronunciar el nombre de república". ${ }^{82}$

La asamblea quedó dominada por los borbonistas, nombre que ya se le daba a Fagoaga, Tagle, Mangino y Odardo. La influencia que este grupo ejercía sobre ella era tal que incluso se rumoraba que "las elecciones para oficios salían de las casas de estos individuos y aunque los del partido de Iturbide hacían esfuerzos para contrabalancear, nunca consiguieron mayoría". ${ }^{83}$ Por si fuese poco, los borbonistas se valie-

${ }^{80}$ Alamán, Historia, p. 492.

81 Para mantener la división de poderes se resolvió que el Congreso legaba interinamente el poder ejecutivo a la Regencia y el judicial a los Tribunales que existian y a los que en el futuro se nombrasen. Sesión del 24 de febrero de 1822 en López, Carlos, 1991, p. 27. Para una explicación detallada sobre la concepción decimonónica de la soberanía, véase Castillo, Apuntamientos, 1976.

${ }^{82}$ Zavala, Ensayo, 1985, vol. I, p. 110.

${ }^{83}$ Ibid., p. 111. ron de un brazo extracongresual: la logia masónica escocesa, y el diario $E l$ Sol que empezó a circular desde 1821.

Los borbonistas no pudieron impedir que Iturbide se proclamara emperador el 19 de mayo de 1822 , hecho que se justificó con el artículo $3^{\circ}$ de los Tratados de Córdoba que especificaban que en caso de que ningún miembro de la familia borbón aceptara la corona mexicana, las Cortes designarían al emperador. ${ }^{84}$

El cada vez más reducido grupo borbonista no cesó su oposición a Iturbide, misma que condujo a prisión a Fagoaga y Tagle la noche del 26 de agosto de 1822 junto con otros trece diputados, entre los que estaban hombres de posiciones políticas tan diversas como Servando Teresa de Mier, Carlos María Bustamante y José Joaquín Herrera. ${ }^{85}$

Las aprehensiones se llevaron a cabo bajo el cargo de conspiración según explicó al propio Congreso el ministro de Relaciones, Manuel Herrera. Lorenzo de Zavala consideraba que el arresto de los diputados fue una "notoria injusticia $[\ldots]$ o un proyecto para eliminar de la asamblea legislativa aquellos diputados que habían manifestado más oposición". ${ }^{86}$ Sin embargo, la defensa que presentó el Congreso en 231.

84 "Tratados", en Matute, México, 1992, p.

${ }^{85}$ Los otros diputados encarcelados fueron Servando de Mier, Echenique, Obregón, Carrasco, Lombardo, Echarte, Pablo Anaya, José del Valle, Juan Mayorga, brigadier Herrera, Carlos María de Bustamante, José Ignacio Gutiérrez Mayorga, Francisco Terrazo y Zevadúa. Zavala, Ensayo, 1985, vol. I, p. 139.

86 Zavala señala que si acaso hubo una "sombra de conspiración, existía en los acalorados 
favor de los diputados presos fue débil ya que le faltó "unidad de respuesta" debido a la heterogénea composición de la asamblea. ${ }^{87}$

La tensión entre el Congreso y el ejecutivo iría aumentando hasta que Iturbide decretó el 31 de octubre su disolución y que en su lugar se instalara una Junta Nacional Instituyente, que habría de iniciar sus trabajos el 2 de noviembre. Para resolver el problema de los diputados presos la flamante Junta aprobó un decreto que establecía que los diputados que cometieran los delitos de "lesa majestad divina o humana" no gozarían de fuero y por tanto serían juzgados como cualquier individuo. 88

En diciembre de 1822 Antonio López de Santa Anna se levantó en armas

cerebros del padre Mier, D. Anastasio Cerecero, D. Juan Pablo Anaya y del ministro de Colombia Santa-María y un tal Itubarría", ibid., p. 140. Para Lucas Alamán la acusación de conspiración en contra de Fagoaga se basaba en que había manifestado que proporcionaría los fondos necesarios para derrocar a Iturbide. Alamán, Historia, 1985, vol. v, p. 653. El ejecutivo, conforme al artículo 172 de la Constitución de Cádiz, podía arrestar a cualquier persona por 48 horas mientras se desahogaban cargos en su contra. Mas siendo diputados que gozaban de fuero, sólo podían ser juzgados por el Congreso. Iturbide se negó a acatar esta disposición alegando que siendo colegas los absolverian. Zavala, Ensayo, 1985, vol. I, p. 141.

${ }^{87}$ Los otros diputados se limitaron a pedir in. formación sobre los encarcelados, y únicamente Zavala, Gómez Farías y Mangino expresaron que los diputados debían de ser entregados al Congreso para que éste los juzgara, ya que gozando de fuero sólo podian ser enjuiciados por su propio tribunal y reglamento. Sesión del 29 de agosto de 1822 en López, Carlos, 1991, pp. 93-94.

88 Ibid., p. 123. en Veracruz con el Plan de Casa Mata; la legitimidad de su pronunciamiento se basó en la disolución del Congreso dictada por Iturbide. El Plan establecía la reinstalación inmediata del Congreso y en su artículo $3^{\circ}$ dejaba a las provincias la posibilidad de reelegir a los diputados que "por sus ideas liberales y firmeza de carácter, se hicieron acreedores del aprecio público". Iturbide se apresuró a reinstalar el Congreso el 7 de marzo de 1823 . De esta manera, los diputados oposicionistas recuperaron su libertad y volvieron a sus curules. ${ }^{89}$

Una vez que Iturbide dimitió a la corona, el Congreso de 1822 fue legítimamente reinstalado. Así el 8 de abril a excepción de los votos en contra de José María Fagoaga y de José María Becerra, el Congreso aprobó la derogación del Plan de Iguala y de los Tratados de Córdoba. El decreto señaló en su artículo primero que "la coronación de $\mathrm{D}$. Agustín de Iturbide fue nula y de ningún valor, por haber sido obra de la fuerza y de la violencia. En consecuencia no ha lugar a su deliberación". 90

Los borbonistas no podían presentar mayores objeciones en contra de este artículo, pero lo que debió molestarles era su corolario que desconocía los Tratados de Córdoba. Éste también se nulificaba con el argumento de que

${ }^{89}$ En un principio Fagoaga junto con otros diputados no acudieron, según se supo en la sesión secreta del 8 de marzo, por temor a posibles represalias. Sin embargo, también manifestaron que en virtud de que el gobierno había publicado el decreto de reistalación acudirian a las sesiones, ibid., p. 131.

${ }^{90}$ Zavala, Ensayo, 1985, vol. I, p. 182. 
Iturbide había sido quien lo había firmado y no la representación mexicana, entonces se concluía que la nación mexicana quedaba libre de cualquier compromiso con la Casa Borbón y "la nación es enteramente libre para constituirse en la forma de gobierno que más le convenga". 91

El Congreso nombró al Supremo Poder Ejecutivo. Las provincias apoyaron la derogación, el partido de los iturbidistas se unió a los republicanos y "el de los borbonistas quedó reducido a completa nulidad".92 Las labores del primer Congreso Constituyente concluyeron el 30 de octubre de 1823. El grupo político del que nos hemos ocupado desaparecía de la palestra, los republicanos habían triunfado.

En la medida en que la sociedad de Los Guadalupes era, si no clandestina por lo menos discreta, resulta dificil conocer el proyecto político que enarbolaron. No obstante es posible inferirlo a partir de su actuación política. Lucharon en primer lugar porque se estableciera la división de poderes, lo que implicaba la reestructuración política del régimen colonial en la que los funcionarios contaban con un patrón de acumulación de funciones en lo relativo a Hacienda, Justicia y Administración. En buena medida por ello se explica la continuidad en la conflictividad entre los poderes ejecutivo y legislativo que se presentó desde 1820.

El segundo elemento de corte liberal que se observa en el pensamiento borbonista era un afán por crear un Estado de derecho formado por ciuda-

91 Ibid.

92 Ibid., p. 183. danos iguales ante la ley. Se ha señalado que los procesos autonomistas e independentistas reavivaron la vieja tradición castellana pactista que reconocía una realidad plural y heterogénea que se expresaba a través de actores colectivos; éste fue el horizonte que compartieron los autonomistas de 1808, los llamados "conservadores", la regencia y el propio Iturbide. Los borbonistas buscaron crear ciudadanos como individuos cuya primera lealtad fuera el Estado simbolizado por el rey, pero sin mediación de cuerpos intermedios tales como el linaje, el ejército, la Iglesia, etc. Para ello resultaba necesario que el mismo Estado garantizara los derechos civiles de los ciudadanos, de ahí la constante defensa de éstos, destacando la lucha por implantar la libertad de imprenta. La construcción del ciudadano implicaba desarticular la organización corporativa de la sociedad novohispana, lo que se expresó en su dictamen en contra de la esclavitud y en sus intentos por establecer la representación popular, pero su celo llegó a tal grado que atentaron incluso contra la organización comunitaria indígena al prohibir el trabajo no remunerado.

Paradójicamente, al recuperarse la legitimidad corporativa en el periodo iturbidista, Fagoaga, Sardaneta y Tagle desempeñaron cargos en la Junta Gubernativa y en el Constituyente basados en una representatividad corporativa que debían al hecho de haber nacido en el seno de la elite novohispana.

El grupo borbonista, que era monárquico constitucionalista, creía en la necesidad de establecer un rey que 
fungiese como un juez supra partes, garantía de unión entre americanos y europeos y árbitro de los diversos intereses sociales y de las contiendas politicas, pero ceñido a una constitución para que no pudiese abusar de sus facultades y quedara libre de toda tentación absolutista. La legitimidad real tradicional había sido hegemónica en Nueva España por lo que la naciente nación mexicana permaneció ligada al rey hasta que éste rompió todo pacto con su reino. La opción republicana sólo fue posible cuando Iturbide se coronó emperador en "búsqueda -vana-de una legitimidad tradicional imposible icómo se podría justificar una legitimidad monárquica cuando el rey no es el 'señor natural' de la comunidad?" Los republicanos entonces retomaron la idea de soberanía popular que ya había sido ensayada en la Constitución de Cádiz, pero negando la tradición de autoridad que daba coherencia a este texto constitucio. nal. ${ }^{93} \mathrm{El}$ establecimiento de la república implicó el acceso al poder de nuevos actores políticos y el diseño de un nuevo orden institucional, mientras que para los borbonistas se tradujo en el fin de su permanencia en el funcionariado por la imposibilidad de llevar a cabo el proyecto monárquico. ${ }^{94}$

93 Guerra, México, 1988, vol. I, p. 192.

94 Cabe destacar que entre los firmantes de la Constitución de 1824 se encuentran algunos ex Guadalupes como José María de la Lave, Rafael Mangino, y José Miguel Guridi y Alcocer, sin embargo hacen falta mayores investigaciones que permitan conocer si Fagoaga, Sardaneta o Sánchez de Tagle continuaron ejerciendo una influencia informal a través de sus ex correligionarios en el Congreso Constituyente.

\section{FUENTES CITADAS: FOLLETERIA}

-Gaceta Imperial Extraordinaria de Méjico, México, 17 de octubre de 1821 .

-Suprema Junta Provisional Gubernativa, Diario de los debates de la Soberana Junta Provisional Gubernativa, Imprenta Imperial de Alejandro Valdés, México, 1822.

Dictamen de la comisión de esclavos, Imprenta Imperial de Alejandro Valdés, México, 24 de octubre de 1821. Dictamen de la comisión de justicia sobre los artículos que deben de tener por fundamentales en el Plan de Iguala y Tratados de Córdoba, el crimen que cometen los que lo ataquen y las penas con que corresponde castigarlos, Imprenta Imperial de Alejandro Valdés, México, 1821.

\section{LIBROS Y ARTÍCULOS}

-Alamán, Lucas, Historia de Méjico, Instituto Helénico/Fondo de Cultura Económica, México, 1985,5 vols.

Benson, Nettie Lee (comp.), México y las cortes españolas, 1810-1812, Instituto de Investigaciones Legislativas-Cámara de Diputados, LII Legislatura, México, 1985. , La diputación provincial y el federalismo mexicano, Instituto de Investigaciones Legislativas-Cámara de Diputados LI Legislatura, México, 1980.

-Brading, David A., Mineros y comerciantes en el México borbónico (17631810), Fondo de Cultura Económica, México, 1976.

-Carmagnani, Marcello, Estado y mercado. La economía pública del liberalismo mexicano, 1850-1911, Fondo de Cultura Económica/El Colegio de México/ Fideicomiso Historia de las Américas, México, 1994.

-Castillo Velasco, José María del, Apuntamientos del derecho constitucional 
mexicano, Comisión Nacional Editorial del Partido Revolucionario Institucional, México, 1976, facsímil de la edición príncipe de 1870.

-Cunnif, Roger L., "La reforma electoral en el municipio, 1810-1822", en Benson, México, 1985.

-De la Torre Villar, Ernesto, Los Guadalupes y la independencia con una selec. ción de documentos inéditos, Editorial Jus, México, 1966.

-Guedea, Virginia, En busca de un gobierno alterno: Los Guadalupes de México, UNAM, México, 1992.

-Guerra, François Xavier, México:del Antiguo Régimen a la revolución, Fondo de Cultura Económica, México, 1988, 2 vols.

-Herrejón Paredo, Carlos (comp.), Actas de la Diputación Provincial de la Nueva España, 1820-1821, Instituto de Investigaciones Legislativas-Cámara de Diputados LII Legislatura, México, 1985.

Jiménez Codinach, Guadalupe, "Introducción al Libro Uno" en Planes en la Nación Mexicana, El Senado de la República LIII Legislatura/El Colegio de México, México, 1987.

-López Betancourt, Raúl Eduardo, Carlos María de Bustamante Legislador
(1822-1824), Instituto de Investigaciones Jurídicas-unaM, México, 1991.

-Matute, Álvaro (comp.), Antología. México en el siglo XIX. Fuentes e interpretaciones históricas, UNAM, México, 1993 (Lecturas Universitarias, 12).

-Neal, Clarice, "La libertad de imprenta en Nueva España, 1810-1822", en Benson, México, 1985.

-Olavarría y Ferrari, Enrique, Méxtco independiente 1821-1855. México a través de los siglos, Editorial Cumbre, México, 1967, vol. IV.

-Pescador, Juan Javier, De bautizados a fieles difuntos. Familia y mentalidades en una parroquía urbana: Santa Catarina de México, 1568-1820, El Colegio de México, México, 1992.

-Tena Ramírez, Felipe, Leyes fundamentales de México, 1808-1987, Editorial Porrúa, México, 1988.

Zárate, Julio, La guerra de Independencia. México a través de los siglos. México independiente 1821-1855, Editorial Cumbre, México, 1967, vol. III.

-Zavala, Lorenzo, Ensayo historico de las revoluciones de México desde 1808 hasta 1830, Instituto Helénico/Fondo de Cultura Económica, México, 1985. 


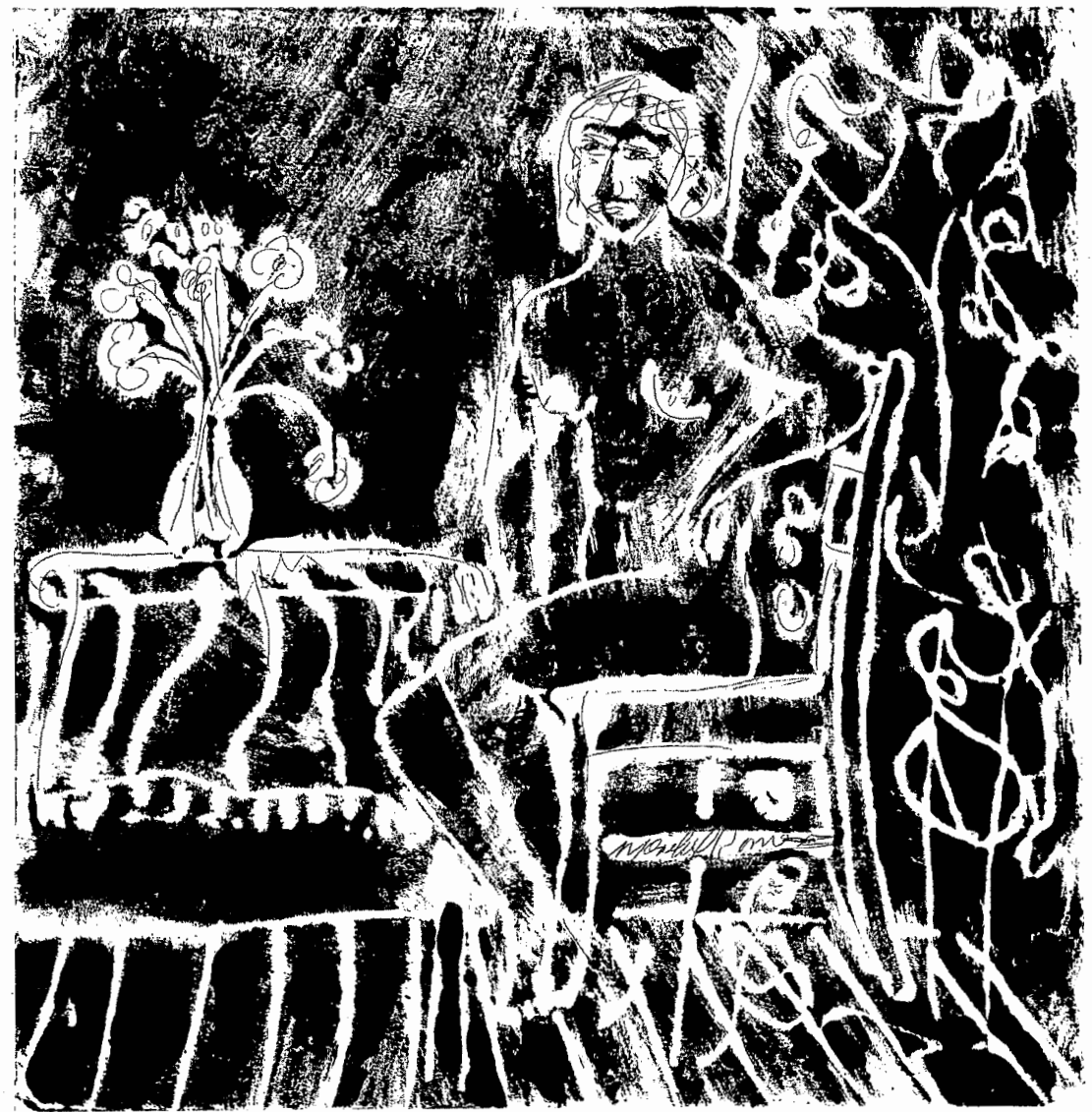

